\title{
Quercetin and rutin as potential agents antifungal against Cryptococcus spp
}

\author{
V. M. Oliveira ${ }^{a}$, E. Carraro ${ }^{a}$, M. E. Auler ${ }^{b}$ and N. M. Khalil \\ aLaboratório de Virologia, Programa de Pós-graduação em Ciências Farmacêuticas, \\ Departamento de Farmácia, Universidade Estadual do Centro-Oeste - UNICENTRO, \\ Rua Simeão Camargo Varelá de Sá, 03, CEP 85040-080, Guarapuava, PR, Brazil \\ bLaboratório de Pesquisa em Fungos Patogênicos, Departamento de Farmácia, Universidade Estadual do Centro-Oeste - \\ UNICENTRO, Rua Simeão Camargo Varelá de Sá, 03, CEP 85040-080, Guarapuava, PR, Brazil \\ 'Laboratório de Nanotecnologia Farmacêutica, Programa de Pós-graduação em Ciências Farmacêuticas, \\ Departamento de Farmácia, Universidade Estadual do Centro-Oeste - UNICENTRO, \\ Rua Simeão Camargo Varelá de Sá, 03, CEP 85040-080, Guarapuava, PR, Brazil \\ *e-mail: vyvymatoso@hotmail.com
}

Received: May 7, 2015 - Accepted: September 11, 2015 - Distributed: November 30, 2016

(With 2 figures)

\begin{abstract}
Amphotericin B is a fungicidal substance that is treatment of choice for most systemic fungal infections affecting as cryptococcosis the immunocompromised patients. However, severe side effects have limited the utility of this drug. The aim of this study was to evaluate the antifungal effect of the combination of amphotericin B with quercetin or rutin and as a protective of citotoxic effect. The antifungal activity to amphotericin $\mathrm{B}$, quercetin and rutin alone and in combination was determined in Candida sp and Cryptococcus neoformans strains. Cytotoxicity test on erythrocytes was performed by spectrophotometric absorbance of hemoglobin. The amphotericin B MIC was reduced when used in combination with quercetin or rutin to C. neoformans ATCC strain and reduced when combined with rutin to a clinical isolate of $C$. neoformans. In addition, the combination of quercetin with amphotericin B may reduce the toxicity of amphotericin B to red blood cells. Our results suggest that quercetin and rutin are potential agents to combine with amphotericin B in order to reduce the amphotericin dose to lessen side effects and improve antifungal efficacy.
\end{abstract}

Keywords: amphotericin B, quercetin, rutin, Cryptococcus neoformans.

\section{Quercetina e rutina: potenciais agentes para terapia antifúngica}

\section{Resumo}

A anfotericina B é uma substância fungicida e é o tratamento de escolha para a maioria das infecções fúngicas sistêmicas que afetam os pacientes imunocomprometidos, como a criptococose. No entanto, as severas reações adversas têm limitado a utilização desta droga. O objetivo deste estudo foi avaliar o efeito antifúngico e o potencial efeito protetor de citotoxicidade da combinação de anfotericina B com quercetina ou rutina. A atividade antifúngica de anfotericina B, quercetina e rutina, isoladamente e em combinação foi determinada em cepas de Candida sp e Cryptococcus neoformans. O teste de citotoxicidade em eritrócitos foi realizado por espectrofotometria, através da determinação da absorbância da hemoglobina. A concentração inibitória mínima da anfotericina B foi reduzida quando utilizada em combinação com a quercetina e rutina em C. neoformans ATCC e reduzida quando combinados com rutina em um isolado clínico de C. neoformans. Além disso, a combinação de quercetina com anfotericina B pode reduzir a toxicidade da droga em eritrócitos. Os resultados sugerem que quercetina e rutina são potenciais agentes para combinação com anfotericina B, a fim de reduzir a dose de anfotericina, diminuindo os efeitos colaterais e melhorando sua eficácia antifúngica.

Palavras-chave: anfotericina B, quercetina, rutina, Cryptococcus neoformans.

\section{Introduction}

Cryptococcus neoformans is a fungal pathogen that causes meningoencephalitis as the most frequent clinical manifestation in immunocompromised patients, mainly in persons infected by HIV. The mortality of disseminated cryptococcosis is $17 \%$ in treated patients with systemic antifungal agents. The treatment regimens for cryptococcal meningitis are focused on amphotericin B (amB) alone or associated with azoles, especially fluconazole (Negroni, 2012). However, the therapy with amB has been limited by severe toxic side effects especially nephrotoxicity 
(Laniado-Laborín and Cabrales-Vargas, 2009). Attempts have been made to reduce amB toxicity by combination with other antifungal agents or natural products because combination therapy can promote synergistic antifungal effect with the advantage of reduced toxicity. This research approach ranges from evaluation of antifungal activity of plant extracts to isolated products plant. Höfling et al. (2010) shows strong activity of Punica granatum, Syzygium cumini, Rosmarinus officinalis, Arrabidaea chica Mentha piperita and Tabebuia avellanedae against Candida species. Giordani et al. (2006) demonstrated that essential oil from Cinnamomum cassia synergistically increased the in vitro antifungal activity of AmB against Candida albicans. Another study demonstrated a synergistic effect between allicin and amB against $C$. albicans (An et al., 2009). Quercetin and Rutin, both polyphenolic flavonoids, stand out among the natural products, through numerous studies. Studies about the antimicrobial activity have shown that quercetin has activity on Staphylococcus aureus and Clostridium botulinum, and in vitro antibacterial activity against the periodontal pathogens Actinobacillus actinomycetemcomitans and Porphyromonas gingivalis (Naghski et al., 1947; Andersen and Berry, 1947; Geoghegan et al., 2010). Other authors also described the action of quercetin against Helicobacter pylori and Escherichia coli as well as synergistic activity with lecithin against Bacillus subtilis and the hepatitis A virus (Wu et al., 2008; Ramadan and Selim Asker, 2009). Rutin was shown to be effective against Bacillus cereus, Salmonella enteritidis and also in the treatment of arthritis caused by Candida albicans (Arima et al., 2002; Pereira et al., 2007; Han, 2009). The aim of this study was to evaluate the antifungal effect of the combination of amB with quercetin or rutin and the potential protective effect of quercetin and rutin on amB cytotoxicity.

\section{Material and Methods}

\subsection{Materials}

Liquid RPMI 1640 medium with L-glutamine and without sodium bicarbonate, morpholinepropanesulfonic acid (MOPS), dimethyl sulfoxide (DMSO), quercetin and rutin was purchased from Sigma ${ }^{\circledR}$ (St. Louis, MO, USA). AmB (Iffect Chemphar Co. Ltd., China).

\subsection{Antifungal activity}

\subsubsection{Strains}

a) Cryptococcus neoformans ATCC 90112 and one clinical isolate of $C$. neoformans. Antifungal activity was determined by broth microdilution using serial dilutions in RPMI 1640 medium, as described by the European Committee for Antibiotic Susceptibility Testing (EUCAST) with some modifications (Rodriguez-Tudela et al., 2008). This protocol was chosen because it provides a better performance of growth for this yeast. b) Candida albicans ATCC 14053, C. albicans ATCC 64546, C. krusei ATCC 6258 and one clinical isolate of Candida tropicalis that was obtained from a blood sample. Antifungal activity was determined by broth microdilution, as described by the Clinical and Laboratory Standards Institute (CLSI, 2008), method M27-A3 with some modifications. The Preparation of stock solution of amB also followed the recommendations of the CLSI.

\subsubsection{Procedure}

RPMI 1640 medium, buffered with 0.165M MOPS, was used for in vitro antifungal analyses. The medium was adjusted to $\mathrm{pH} 7.0$ and filtered. An amB stock solution was prepared in DMSO, and stock solutions of quercetin and rutin were prepared in ethanol.

a) Cell suspensions of two strains of $C$. neoformans were prepared in RPMI medium with $2 \%$ glucose and adjusted to give final inoculum concentrations of $0.5 \times 10^{5}$ a $2.5 \times 10^{5}$ CFU.mL ${ }^{-1}$ (EUCAST). The cells were incubated with different concentrations $(125-31.25 \mu \mathrm{g}$. $\mathrm{mL}^{-1}$ ) of quercetin and rutin alone and in combination with amB $\left(16-0.03 \mu \mathrm{g} \cdot \mathrm{mL}^{-1}\right)$ at $37{ }^{\circ} \mathrm{C}$ for 24 hours. The concentrations of natural compounds were chosen since they were the best concentrations in soluble RPMI. Medium alone inoculated with the fungal strain was used as a growth control, and uninoculated medium was used as the blank control. The minimum inhibitory concentration (MIC) was defined as the lowest concentration that does not result in any visible growth of the yeast compared to the control. Each concentration was assessed in triplicate and in two independent experiments. The reading was always performed by more than one observer. To confirm the absence or reduction of growth, the content of each source was diluted 1:100 in saline and $20 \mu \mathrm{L}$ of each suspension was streaked in triplicate onto Sabouraud dextrose agar plates (Barchiesi et al., 2007). The plates were incubated at $35 \pm 2{ }^{\circ} \mathrm{C}$ for $48 \mathrm{~h}$ and the number of colonies on each plate was counted. The results were statistically analyzed by ANOVA with $95 \%$ confidence $(\alpha=0.05)$ and post hoc Tukey.

b) Cell suspensions of Candida spp. strains were prepared in RPMI medium and adjusted to give final inoculum concentrations of $0.5 \times 10^{3}$ to $5 \times 10^{3} \mathrm{CFU} \cdot \mathrm{ml}^{-1}$. The cells were incubated with different concentrations of quercetin and rutin and/or amB at $37{ }^{\circ} \mathrm{C}$ for 48 hours. Medium alone inoculated with the fungal strain was used as a growth control, and uninoculated medium was used as the blank control. The minimum inhibitory concentration (MIC) was defined as the lowest concentration that does not result in any visible growth of the yeast compared to the control. Each concentration was assessed in triplicate and two independent experiments, the reading being performed always by more than one observer.

The quality control was performed with C. krusei ATCC 6258 and C. parapsilosis ATCC 22019 in accordance with the recommendations of the CLSI M27-A3. The controls shown to be within the parameters established which makes 
the validated experiment. The Ethics Committee of the Universidade Estadual do Centro-Oeste, Guarapuava, Brazil, approved all experiments. (Protocol COMEP 193/2011).

\subsection{Cytotoxicity in vitro on human erythrocytes}

\subsubsection{Preparation of erythrocyte suspension}

Freshly collected human blood, obtained from one healthy donor, was treated with $10 \mu \mathrm{L}$ of heparin (5.000UI/mL, Cristália Ltda) and centrifuged at 2500rpm for $5 \mathrm{~min}$ to separate the plasma from the erythrocytes. The pelleted erythrocytes were washed three times with isotonic PBS (pH7.4), and the supernatant was carefully removed after each wash. After the final wash, the packed cells were re-suspended in PBS, and the hematocrit was determined (Koga et al., 1998). The Ethics Committee of the Universidade Estadual do Centro-Oeste, Guarapuava, Brazil, approved all experiments. (Protocol COMEP 193/2011).

\subsubsection{Hemolysis measurements}

The hemolysis studies were performed with erythrocytes suspended in PBS (3mL) at a hematocrit of $2 \%$. A $0.037 \mathrm{~mL}$ volume of free $\mathrm{AmB}\left(10 \mu \mathrm{g} \cdot \mathrm{mL}^{-1}\right)$ in DMSO was added to the cell suspension. The final DMSO concentration $(1.0 \%)$ in the suspension had no effect on the erythrocytes. The quercetin and rutin in ethanol were added to the suspensions at different concentrations $\left(6.25-200 \mu \mathrm{g} \cdot \mathrm{mL}^{-1}\right)$. Erythrocytes suspended in PBS were used as a blank control. Suspensions containing only free Amb were used as positive controls of hemolysis. The suspensions were incubated at $37{ }^{\circ} \mathrm{C}$ with continuous shaking in the dark and were monitored until the controls showed significant hemolysis. After incubation, the erythrocyte suspensions were centrifuged at 2500rpm for $5 \mathrm{~min}$ and the hemolysis degree was estimated by visible spectroscopy at 540nm from the hemoglobin released into the supernatant (Koga et al., 1998). The results are expressed as the percentage of inhibition of AmB-induced hemolysis, calculated according to the following formula: hemolysis inhibition $\%=[(\mathrm{Ab}-\mathrm{Aa}) / \mathrm{Ab}] \times 100$, where $\mathrm{Ab}$ is the absorption of the control and Aa is the absorption of the sample (Dypbukt et al., 2005).

\section{Results and Discussion}

The results show that quercetin and rutin alone showed no antifungal effects against $C$. neoformans. However, when these compounds were tested associated with amB they showed improvement in antifungal activity of amB. According to Table 1, in C. neoformans ATCC 90112, the amB MIC was $0.25 \mu \mathrm{g} . \mathrm{mL}^{-1}$; however, when used in combination with quercetin

(at concentrations of $31.25,62.5$ and $125 \mu \mathrm{g} . \mathrm{mL}^{-1}$ ) or rutin (at a concentration of 62.5 and $125 \mu \mathrm{g} \cdot \mathrm{mL}^{-1}$ ), this value was reduced to $0.125 \mu \mathrm{g} \cdot \mathrm{mL}^{-1}$ and $0.0625 \mu \mathrm{g} \cdot \mathrm{mL}^{-1}$, respectively. When rutin was tested at a concentration of $31.25 \mu \mathrm{g} \cdot \mathrm{mL}^{-1}$, the amB MIC was reduced to $0.125 \mu \mathrm{g} \cdot \mathrm{mL}^{-1}$. In relation to the clinical isolate of $C$. neoformans, the $\mathrm{amB}$ MIC was also $0.25 \mu \mathrm{g} \cdot \mathrm{mL}^{-1}$, and in combination with rutin $\left(125 \mu \mathrm{g} \cdot \mathrm{mL}^{-1}\right)$ this concentration was reduced to $0.0625 \mu \mathrm{g}$.
Table 1. Results of susceptibility test for determining the MIC of amB, quercetin and rutin alone and in combination against two strains of Cryptococcus neoformans by broth microdilution assay.

\begin{tabular}{|c|c|c|}
\hline \multirow[b]{2}{*}{ Compounds } & \multicolumn{2}{|c|}{ CIM ( gg.mL $\left.^{-1}\right)$} \\
\hline & $\begin{array}{c}\text { Cryptococcus } \\
\text { neoformans } \\
\text { ATCC } 90012\end{array}$ & $\begin{array}{c}\text { Cryptococcus } \\
\text { neoformans } \\
\text { Clinical isolate }\end{array}$ \\
\hline $\begin{array}{l}\text { Amphotericin } \\
\text { (AmB) }\end{array}$ & 0.25 & 0.25 \\
\hline Quercetin (QR) & $>125$ & $>125$ \\
\hline Rutin (RUT) & $>125$ & $>125$ \\
\hline $\begin{array}{l}\mathrm{AmB}+\mathrm{QR} \\
(125 \mu \mathrm{g} / \mathrm{mL})\end{array}$ & 0.125 & 0.25 \\
\hline $\begin{array}{l}\mathrm{AmB}+\mathrm{QR} \\
(62.5 \mu \mathrm{g} / \mathrm{mL})\end{array}$ & 0.125 & 0.25 \\
\hline $\begin{array}{l}\mathrm{AmB}+\mathrm{QR} \\
(31.25 \mu \mathrm{g} / \mathrm{mL})\end{array}$ & 0.125 & 0.25 \\
\hline $\begin{array}{l}\text { AmB + RUT } \\
(125 \mu \mathrm{g} / \mathrm{mL})\end{array}$ & 0.0625 & 0.0625 \\
\hline $\begin{array}{l}\text { AmB + RUT } \\
(62.5 \mu \mathrm{g} / \mathrm{mL})\end{array}$ & 0.0625 & 0.25 \\
\hline $\begin{array}{l}\text { AmB+RUT } \\
(31.25 \mu \mathrm{g} / \mathrm{mL})\end{array}$ & 0.125 & 0.25 \\
\hline
\end{tabular}

$\mathrm{mL}^{-1}$. These results were confirmed by counting the CFU that are presented in Figure 1. It was observed that amB tested at a subinibitory concentration showed no effect on the CFU count; however, when used in combination with quercetin (Figure 1b) and rutin (Figures 1a and c) the CFU count was reduced significantly $(p<0,05)$. Thus the CFU counts confirm and complement the results obtained in tests microdilution broth which also corroborates their validation. Although quercetin and rutin alone and in combination with amB showed no effects on the Candida strains. The MIC value for amB on Candida albicans ATCC 14053 and ATCC 64546 was $0.025 \mu \mathrm{g} . \mathrm{mL}^{-1}$ and on Candida kruzei ATCC 6258 and Candida tropicalis were $0.25 \mu \mathrm{g} \cdot \mathrm{mL}^{-1}$ and $0.5 \mu \mathrm{g} \cdot \mathrm{mL}^{-1}$ respectively. The MICs values for amB combined with quercetin and rutin which were the same as found for amphotericin tested alone on all strains tested.

The good effect found for Cryptococcus strains suggests that the mechanism of action of these compounds can be related to the structure of these yeasts. These results corroborate the study by Faria et al. (2011) that show enhanced activity of antifungal amB using natural phenolics compounds against strains of Cryptococcus sp. The amB is toxic because of its high affinity for the ergosterol that is cholesterol analogue present in mammalian cell membranes. Thus, its use has been limited in many patients because it almost always results in some degree of renal impairment, which ranges in severity depending on the total dose (Park et al., 2011). Thus, a more rational treatment could be the combination of amB with compounds that enhance its action, so that smaller doses of drug can 

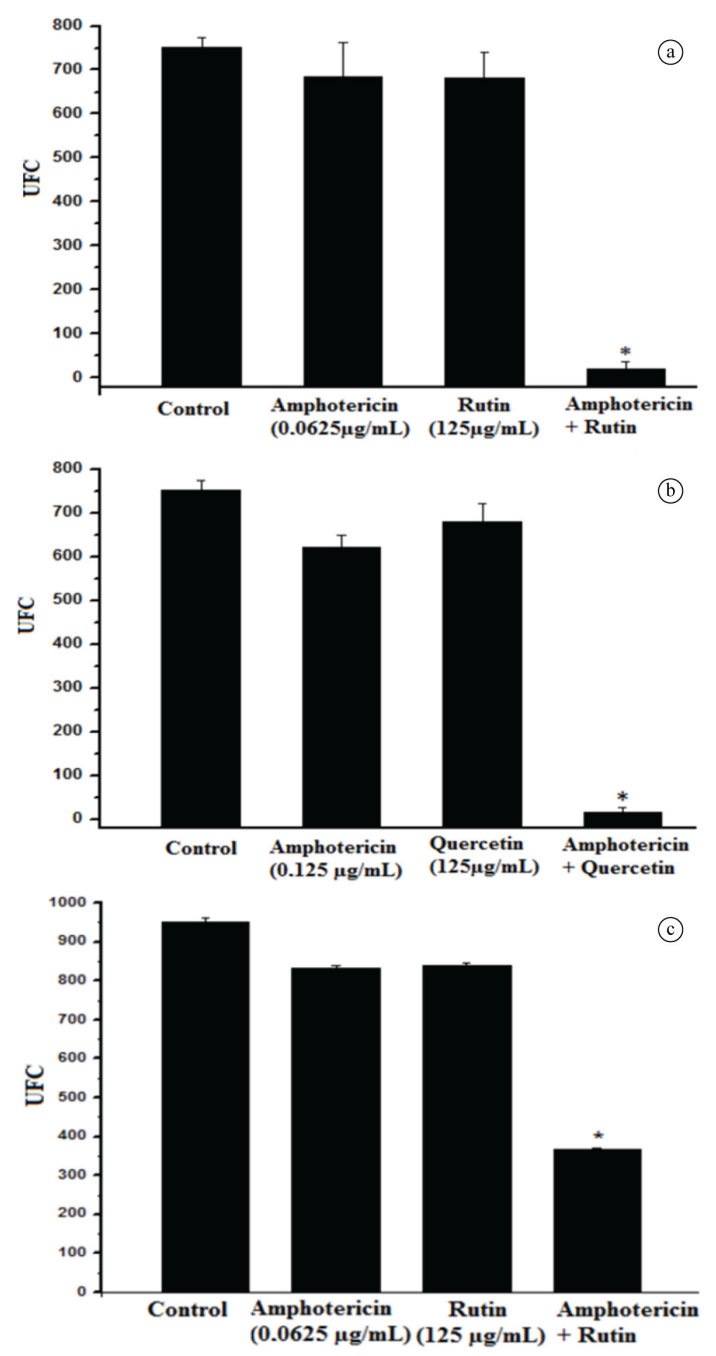

Figure 1. Effect of quercetin, rutin and $\mathrm{amB}$ alone and combination on mean growth (CFU) of $C$. neoformans ATCC 90012 (a and b) and clinical isolate C. neoformans (c) in sabouraud dextrose agar plate. Colony counts were determined after incubation at $37{ }^{\circ} \mathrm{C}$ for $48 \mathrm{~h}$, of triplicate cultures \pm standard deviation. ${ }^{*}$ Combination of amphotericin $\left(0.0625 \mu \mathrm{g} \cdot \mathrm{mL}^{-1}\right)+\operatorname{rutin}\left(125 \mu \mathrm{g} \cdot \mathrm{mL}^{-1}\right)$ or amphotericin $\left(0.125 \mu \mathrm{g} \cdot \mathrm{mL}^{-1}\right)+$ quercetin $\left(125 \mu \mathrm{g} \cdot \mathrm{mL}^{-1}\right)$ was significantly different from all other groups. $(\mathrm{p}<0.05)$.

be used, or with compounds that protect cells or tissues that are targets of amB-mediated toxicity. Some studies have already explored this possibility. For example, one group demonstrated the synergistic activity of grape seed extract (Vitis vinifera) and amB against Candida $\mathrm{sp}$ (Han, 2007b). This effect was also observed when amB was combined with the natural compounds berberine, alicin, epigallocatechin gallate and with essential oils of Melaleuca alternifolia, Origanum vulgare, Pelargonium graveolens, Cinnamomum cassia, Coriandrum sativum, Thymus maroccanus e Thymus broussonetii (Han and Lee, 2005; Han, 2007a; Rosato et al., 2008; An et al., 2009; Saad et al., 2010; Silva et al., 2011).

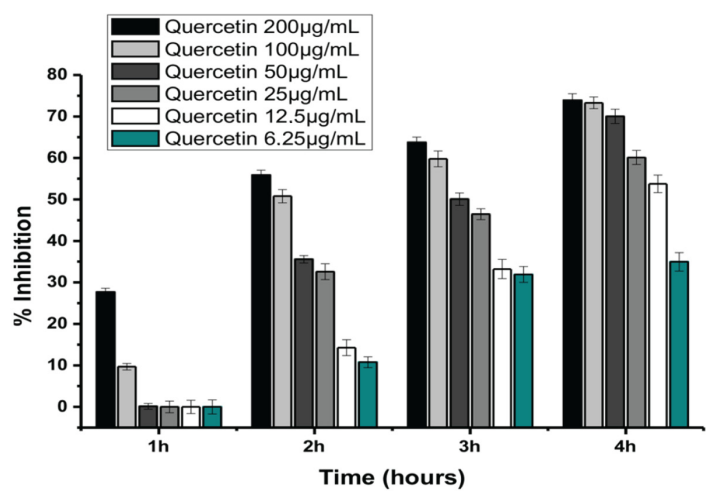

Figure 2. Inhibitory effect of different concentrations $\left(6.25-200 \mu \mathrm{g} . \mathrm{mL}^{-1}\right)$ of quercetin in hemolysis induced by amphotericin B $\left(10 \mu \mathrm{g} \cdot \mathrm{mL}^{-1}\right)$.

The number of studies with natural products that show increased activity of amB on strains of Cryptococcus $\mathrm{sp}$ is much lower than found for strains of Candida sp. Davis et al. (1994) show an in vitro synergistic fungistatic activity effect of concentrated Allium sativum extract with amB against $C$. neoformans. Another study also showed an increase in antifungal activity of amB in the presence of acteoside, a phenylethanoid glycoside from Colebrookea oppositifolia (Ali et al., 2011).

The mechanisms involved in synergy with amphotericin and most of the natural compounds are not well understood. However, several studies suggest that the subinhibitory concentrations of amB facilitated the uptake of natural compounds, which resulted in increased killing of the fungal cells (Hirasawa and Takada, 2004; Ali et al., 2011).

Our results suggest that quercetin and rutin enhance the antifungal activity of amB. Additional in vivo tests are required to perform synergy tests and to evaluate the antimicrobial potential of these compounds for optimize the therapeutic conduct and reduce the toxic effects of the drug. The toxicity tests show that quercetin protects red blood cells from amB-mediated toxicity. The inhibition of hemolysis by quercetin was dose-dependent and increased with time (Figure 2). Initially, quercetin showed an inhibition of hemolysis of $27.69 \%, 8.82 \%$ and $1.65 \%$ at concentrations of $200 \mu \mathrm{g} \cdot \mathrm{mL}^{-1}, 100 \mu \mathrm{g} \cdot \mathrm{mL}^{-1}$ and $50 \mu \mathrm{g} \cdot \mathrm{mL}^{-1}$, respectively. After four hour the inhibition of hemolysis was $55.86 \%, 50.79 \%, 35.57 \%, 32.58 \%, 14.63 \%$ and $10.77 \%$ at concentrations of $200 \mu \mathrm{g} \cdot \mathrm{mL}^{-1} 100 \mu \mathrm{g} \cdot \mathrm{mL}^{-1}, 50 \mu \mathrm{g} \cdot \mathrm{mL}^{-1}$, $25 \mu \mathrm{g} . \mathrm{mL}^{-1}, 12.5 \mu \mathrm{g} . \mathrm{mL}^{-1}$ and $6.25 \mu \mathrm{g} . \mathrm{mL}^{-1}$, respectively. Inhibitory effect was not observed with rutin. Studies have shown the involvement of oxidative stress in the antifungal activity of amB. This process may be explained by the generation of reactive oxygen species and hydroxyl radicals, promoted by the drug, leading to fungal cell damage through oxidation of proteins, peroxidation of membrane lipids or DNA or RNA cleavage (Brajtburg et al., 1985). Our results show that when amB is used with quercetin (potent antioxidant compound) cellular toxic effects are reduced. This reveals that quercetin is a potential adjunct to antifungal therapy with amB. 


\section{Conclusion}

The current limitations in antifungal therapy stimulate the search for new alternatives to achieve therapeutic success. Among them are natural products that are attractive prototypes for this purpose, due to their broad spectrum of biological activity and their abundance in nature and low cost. Our results do suggest that quercetin and rutin are potential therapeutic agents for use in combination with amB since it has the advantage of reducing the toxicity of the drug and also improves their antifungal activity. But more studies are needed to determine the potential utility of this combination therapy.

\section{References}

ALI, I., SHARMA, P., SURI, K.A., SATTI, N.K., DUTT, P., AFRIN, F. and KHAN, I.A., 2011. In vitro antifungal activities of amphotericin B in combination with acteoside, a phenylethanoid glycoside from Colebrookea oppositifolia. Journal of Medical Microbiology, vol. 60, no. 9, pp. 1326-1336. http://dx.doi. org/10.1099/jmm.0.031906-0. PMid:21474610.

AN, M.M., SHEN, H., CAO, Y.B., ZHANG, J.D., CAI, Y., WANG, R. and JIANG, Y.Y., 2009. Allicin enhances the oxidative damage effect of amphotericin B against Candida albicans. International Journal of Antimicrobial Agents, vol. 33, no. 3, pp. 258-263. http:// dx.doi.org/10.1016/j.ijantimicag.2008.09.014. PMid:19095412.

ANDERSEN, A.A. and BERRY, J.A., 1947. Effect of flavonols on Clostridium botulinum. Science, vol. 106, no. 2765, pp. 644-645. http://dx.doi.org/10.1126/science.106.2765.644-a. PMid:17741557.

ARIMA, H., ASHIDA, H. and DANNO, G., 2002. Rutinenhanced antibacterial activities of flavonoids against Bacillus cereus and Salmonella enteritidis. Bioscience, Biotechnology, and Biochemistry, vol. 66, no. 5, pp. 1009-1014. http://dx.doi. org/10.1271/bbb.66.1009. PMid:12092809.

BARCHIESI, T., GIACOMETTI, A., CIRIONI, O., ARZENI, D., SILVESTRI, C., KAMYSZ, W., ABBRUZZETTI, A., RIVA, A., KAMYSZ, E. and SCALISE, G., 2007. In vitro activity of the synthetic lipopeptide PAL-Lys-Lys-NH2 alone and in combination with antifungal agents against clinical isolates of Cryptococcus neoformans. Peptides, vol. 28, no. 8, pp. 1509-1513. http://dx.doi. org/10.1016/j.peptides.2007.07.010. PMid:17698253.

BRAJTBURG, J., ELBERG, S., SCHWARTZ, D.R., VERTUTCROQUIN, A., SCHLESSINGER, D., KOBAYASHI, G.S. and MEDOFF, G., 1985. Involvement of Oxidative Damage in Erythrocyte Lysis Induced by Amphotericin B. Antimicrobial Agents and Chemotherapy, vol. 27, no. 2, pp. 172-176. http:// dx.doi.org/10.1128/AAC.27.2.172. PMid:3985601.

CLINICAL AND LABORATORY STANDARDS INSTITUTE - CLSI, 2008. M27-A3: reference method for both dilution antifungal susceptibility testing of yeasts: approved standard. 3rd ed. Wayne: Clinical and Laboratory Institute.

DAVIS, L.E., SHEN, J. and ROYER, R.E., 1994. In vitro synergism of concentrated Allium sativum extract and amphotericin B against Cryptococcus neoformans. Planta Medica, vol. 60, no. 6, pp. 546549. http://dx.doi.org/10.1055/s-2006-959568. PMid:7809209.

DYPBUKT, J.M., BISHOP, C., BROOKS, W.M., THONG, B., ERIKSSON, H. and KETTLE, A.J., 2005. A sensitive and selective assay for chloramine production by myeloperoxidase. Free Radical
Biology \& Medicine, vol. 39, no. 11, pp. 1468-1477. http://dx.doi. org/10.1016/j.freeradbiomed.2005.07.008. PMid:16274882.

FARIA, N.C., KIM, J.H., GONÇALVES, L.A., MARTINS, M.L., CHAN, K.L. and CAMPBELL, B.C., 2011. Enhanced activity of antifungal drugs using natural phenolics against yeast strains of Candida and Cryptococcus. Letters in Applied Microbiology, vol. 52, no. 5, pp. 506-513. http://dx.doi.org/10.1111/j.1472765X.2011.03032.x. PMid:21332761.

GEOGHEGAN, F., WONG, R.W. and RABIE, A.B., 2010. Inhibitory effect of quercetin on periodontal pathogens in vitro. Phytotherapy Research, vol. 24, no. 6, pp. 817-820. PMid:19957242.

GIORDANI, R., REGLI, P., KALOUSTIAN, J. and PORTUGAL, H., 2006. Potentiation of antifungal activity of Amphotericin B by essential oil from Cinnamomum cassia. Phytotherapy Research, vol. 20, no. 1, pp. 58-61. http://dx.doi.org/10.1002/ptr.1803. PMid:16397923.

HAN, Y., 2007a. Synergic anticandidal effect of epigallocatechin$O$-gallate combined with amphotericin B in a murine model of disseminated candidiasis and its anticandidal mechanism. Biological \& Pharmaceutical Bulletin, vol. 30, no. 9, pp. 1693-1696. http:// dx.doi.org/10.1248/bpb.30.1693. PMid:17827722.

HAN, Y., 2007b. Synergic effect of grape seed extract with amphotericin B against disseminated candidiasis due to Candida albicans. Phytomedicine, vol. 14, no. 11, pp. 733-738. http:// dx.doi.org/10.1016/j.phymed.2007.08.004. PMid:17913484.

HAN, Y., 2009. Rutin has therapeutic effect on septic arthritis caused by Candida albicans. International Immunopharmacology, vol. 9, no. 2, pp. 207-211. http://dx.doi.org/10.1016/j.intimp.2008.11.002. PMid:19041425.

HAN, Y. and LEE, J.H., 2005. Berberine Synergy with Amphotericin $\mathrm{B}$ against Disseminated Candidiasis in Mice. Biological \& Pharmaceutical Bulletin, vol. 28, no. 3, pp. 541-544. http://dx.doi. org/10.1248/bpb.28.541. PMid:15744087.

HIRASAWA, M. and TAKADA, K., 2004. Multiple effects of green tea catechin on the antifungal activity of antimycotics against Candida albicans. The Journal of Antimicrobial Chemotherapy, vol. 53, no. 2, pp. 225-229. http://dx.doi.org/10.1093/jac/dkh046. PMid:14688042.

HÖFLING, J.F., ANIBAL, P.C., OBANDO-PEREDA, G.A., PEIXOTO, I.A.T., FURLETTI, V.F., FOGLIO, M.A. and GONÇALVES, R.B., 2010. Antimicrobial potential of some plant extracts against Candida species. Brazilian Journal of Biology $=$ Revista Brasileira de Biologia, vol. 70, no. 4, pp. 1065-1068. http:// dx.doi.org/10.1590/S1519-69842010000500022. PMid:21180915.

KOGA, T., MORO, K. and TERAO, J., 1998. Protective effects of a vitamin $\mathrm{E}$ analog, phosphatidylchromanol, against oxidative hemolysis of human erythrocytes. Lipids, vol. 33, no. 6, pp. 589595. http://dx.doi.org/10.1007/s11745-998-0244-4. PMid:9655374.

LANIADO-LABORÍN, R. and CABRALES-VARGAS, M.N., 2009. Amphotericin B: side effects and toxicity. Revista Iberoamericana de Micologia, vol. 26, no. 4, pp. 223-227. http:// dx.doi.org/10.1016/j.riam.2009.06.003. PMid:19836985.

NAGHSKI, J., COPLEY, M.J. and COUCH, J.F., 1947. Effect of flavonols on the bacteriostatic action of Dicoumarol. Science, vol. 105 , no. 2718 , pp. 125-126. http://dx.doi.org/10.1126/ science.105.2718.125. PMid:17813639.

NEGRONI, R., 2012. Cryptococcosis. Clinics in Dermatology, vol. 30, no. 6, pp. 599-609. http://dx.doi.org/10.1016/j. clindermatol.2012.01.005. PMid:23068147. 
PARK, B.J., TAGUCHI, H., KAMEI, K., MATSUZAWA, T., HYON, S.H. and PARK, J.C., 2011. In vitro antifungal activity of epigallocatechin 3-O-gallate against clinical isolates of dermatophytes. Yonsei Medical Journal, vol. 52, no. 3, pp. 535-538. http://dx.doi.org/10.3349/ymj.2011.52.3.535. PMid:21488200.

PEREIRA, A., FERREIRA, I., MARCELINO, F., VALENTÃO, P., ANDRADE, P., SEABRA, R., ESTEVINHO, L., BENTO, A. and PEREIRA, J.A., 2007. Phenolic compounds and antimicrobial activity of olive (Olea europaea L. Cv. 'Cobrançosa'). Molecules, vol. 12, no. 5, pp. 1153-1162. http://dx.doi.org/10.3390/12051153. PMid:17873849.

RAMADAN, M.F. and SELIM ASKER, M.M., 2009. Antimicrobial and antiviral impact of nevel quercetina-enriched lecithin. Journal of Food Biochemistry, vol. 33, no. 4, pp. 557-571. http://dx.doi. $\operatorname{org} / 10.1111 / \mathrm{j} .1745-4514.2009 .00237 . x$.

RODRIGUEZ-TUDELA, J.L., ARENDRUP, M.C., BARCHIESI, F., BILLE, J., CHRYSSANTHOU, E., CUENCA-ESTRELLA, M., DANNAOUI, E., DENNING, D.W., DONNELLY, J.P., DROMER, F., FEGELER, W., LASS-FLÖRL, C., MOORE, C., RICHARDSON, M., SANDVEN, P., VELEGRAKI, A. and VERWEIJ, P., 2008. EUCAST definitive document EDef 7.1: method for the determination of broth dilution MICs of ntifungal agents for fermentative yeasts. Clinical Microbiology and Infection, vol. 14, no. 4, pp. 398-405. http://dx.doi.org/10.1111/j.14690691.2007.01935.x. PMid:18190574.

ROSATO, A., VITALI, C., GALLO, D., BALENZANO, L. and MALLAMACI, R., 2008. The inhibition of Candida species by selected essential oils and their synergism with amphotericin B. Phytomedicine, vol. 15, no. 8, pp. 635-638. http://dx.doi. org/10.1016/j.phymed.2008.05.001. PMid:18579358.

SAAD, A., FADLI, M., BOUAZIZ, M., BENHARREF, A., MEZRIOUI, N.E. and HASSANI, L., 2010. Anticandidal activity of the essential oils of Thymus maroccanus and Thymus broussonetii and their synergism with amphotericin B and fluconazol. Phytomedicine, vol. 17, no. 13, pp. 1057-1060. http:// dx.doi.org/10.1016/j.phymed.2010.03.020. PMid:20554185.

SILVA, F., FERREIRA, S., DUARTE, A., MENDONÇA, D.I. and DOMINGUES, F.C., 2011. Antifungal activity of Coriandrum sativum essential oil, its mode of action against Candida species and potential synergism with amphotericin B. Phytomedicine, vol. 19, no. 1, pp. 42-47. http://dx.doi.org/10.1016/j.phymed.2011.06.033. PMid:21788125.

WU, D., KONG, Y., HAN, C., CHEN, J., HU, L., JIANG, H. and SHEN, X., 2008. D-Alanine:D-alanine ligase as a new target for the flavonoids quercetin and apigenin. International Journal of Antimicrobial Agents, vol. 32, no. 5, pp. 421-426. http://dx.doi. org/10.1016/j.ijantimicag.2008.06.010. PMid:18774266. 